\title{
LIST OF MAPS, PHOTOGRAPHS AND TABLES
}

Maps

1.1 States and Polities between the Zambezi and the Limpopo c. 1890

1.2 A Political Geography of Katerere c. 1880

4.1 The Distribution of Churches and Mhondoro Cults in Katerere in the 1950s and 1960s

5.1 Northern Inyanga District during the Liberation War 118

6.1 The Territorial Basis of Contemporary Factional Politics 148

7.1 The Distribution of Churches and Mhondoro Cults in Katerere in the late 1980 s and 1990 s

\section{Photographs}

1.1 Mt Nhani

1.2 Mt Mhokore

2.1 Brother Aegidius Pfister

3.1 A Hwesa elder in front of his house, c.1951 79

$\begin{array}{ll}\text { 3.2 Mary Brien in front of her house, c.1951 } & 79\end{array}$

3.3 and 3.4 The Founding and Early Days of Elim, Katerere 80

3.5 and 3.6 Medical Work and Afternoon Tea in Elim, Katerere 84

3.7 The Hwesa-style Church at Avila Mission 89

3.8 Elim Baptism in a Mountain Pool 89

$\begin{array}{ll}5.1 \text { Diki Rukadza, Medium of Nyawada } & 132\end{array}$

5.2 Razau Kaerezi, Medium of Chikumbirike 132

6.1 Interview with Chief Njanji Katerere 152

6.2 Langton Muromowenyoka in his field, with his son, Onias 152

$\begin{array}{ll}6.3 \text { 'Official' Chief, Matambo Chifodya } & 171\end{array}$

$\begin{array}{ll}\text { 6.4 Matambo Chifodya and his Council } & 171\end{array}$

6.5 Patrick Tsodza and Members of his Council 172

$\begin{array}{ll}\text { 6.6 Patrick Tsodza presiding over a First Fruits Ceremony, } & 172 \\ \text { as 'Popular' Chief } & 172\end{array}$

$\begin{array}{lll}7.1 & \text { Elim Women Dancing at a Wedding } & 214\end{array}$ 


\section{Tables}

1.1 The Territorial Basis of Factional Politics during the Making of the Katerere Polity

1.2 A Summary of Hwesa Legends with reference to Factional Politics

6.1 Key Players in Katerere's Factional Politics 